Vol. 1 No. 02 Hal. 20 - 27

September 2018

\title{
Pengaruh Model Three Stage Fishbowl Terhadap Hasil Belajar Siswa Pada Materi Ekosistem Di Kelas X SMA Swasta Persiapan Stabat TP 2016/2017
}

\author{
${ }^{(1)}$ Edi Azwar, ${ }^{(2)}$ Anggun Ninda Syahputri \\ Dosen PNS Kopertis Wilayah I Sumatera Utara DPK UISU ${ }^{(2)}$ \\ Alumni Program Studi Pendidikan Biologi UISU ${ }^{(1)}$ \\ Email : Ediazwar@ fkip.uisu.ac.id ${ }^{(1)}$, ninda4nggun@yahoo.co.id $^{(2)}$
}

\begin{abstract}
ABSTRAK
Penelitian ini bertujuan untuk mengetahui pengaruh penggunaan Model Three Stage Fishbowl Terhadap Hasil Belajar Siswa Pada Materi Ekosistem Di SMA SWASTA PERSIAPAN STABAT Medan Tahun Pembelajaran 2015/2016. Populasi dalam penelitian ini adalah kelas X yang terdiri dari 4 kelas yang berjumlah 136 siswa. Pengambilan sampel dilakukan secara acak (random sampling). Sampel dalam penelitian ini adalah kelas $\mathrm{X}^{3}$ yang berjumlah 30 siswa. Nilai rata-rata pre-tes 59,56 dengan standar deviasi 14,00 sedangkan nilai rata-rata post-tes 74,56 dengan standar deviasi 12,40 bserdasarkan uraian di atas terdapat peningkatan antara nilai rata-rata pre-tes dengan nilai rata-rata pos-tes dari 59,56 menjadi 74,56 mencapai nilai Kriteria Ketuntasan Minimal (KKM)yaitu 75. Uji hipotesis di dapat nilai $t_{\text {hitung }} 9,93$ sedangkan nilai $t_{\text {tabel }}$ 1,70 sehinggan $t_{\text {hitung }}>t_{\text {tabel }}$, dengan demikian Ho di tolak dan Ha diterima dan dapat disimpulkan bahwa ada pengaruh yang signifikan penggunaan Model Three Stage Fishbowl Terhadap Hasil Belajar Siswa Pada Materi Ekosistem Di SMA SWASTA PERSIAPAN STABAT Tahun Pembelajaran 2015/2016.
\end{abstract}

\begin{abstract}
This study aims to determine the effect of using the Three Stage Fishbowl Model on Student Learning Outcomes on Ecosystem Material in PERSIAPAN PRIVATE VOCATIONAL SCHOOL OF STABAT Medan in the 2015/2016 Learning Year. The population in this study is class X which consists of 4 classes totaling 136 students. Sampling is done randomly. The sample in this study is class X3, amounting to 30 students. The average value of the pre-test was 59.56 with a standard deviation of 14.00 while the average post-test score was 74.56 with a standard deviation of 12.40 based on the description above, there was an increase between the average pre-test score and the average score the post-test from 59.56 to 74.56 reached the Minimum Passing Criteria (KKM) value of 75. Based on the hypothesis test can get the value of 9.93, while the value of table 1.70 so that $t$ count $>t$ table, thus Ho is rejected and $\mathrm{Ha}$ is accepted and it can be concluded that there is a significant effect of using the Three Stage Fishbowl Model on Student Learning Outcomes in the Ecosystem Material STABAT PREPARATION PRIVATE VOCATIONAL SCHOOL, 2015/2016 Learning Year.
\end{abstract}

\section{PENDAHULUAN}

\section{Latar Belakang}

Belajar merupakan kegiatan individu untuk memperoleh pengetahuan, perilaku yang baik dan keterampilan tertentu dengan cara mengolah bahan ajar atau bahan pelajaran. Sedangkan mengajar adalah penciptaan sistem lingkungan yang memungkinkan terjadinya proses belajar mengajar. Sistem lingkungan ini terdiri dari komponen-komponen yang saling mempengaruhi satu dengan yang lainya, yakni tujuan pembelajaran yang ingin dicapai, materi yang akan diajarkan, guru dan peserta didik yang harus memainkan peranan serta ada dalam hubungan sosial tertentu, jenis kegiatan yang dilakukan, serta sarana dan prasarana belajar mengajar yang tersedia. Belajar Biologi merupakan suatu kegiatan yang mempelajari tentang alam dan segala hal yang berkaitan dengan makhluk hidup. Biologi merupakan salah satu cabang ilmu sains yang mempelajari tentang seluk beluk makhluk 
hidup yang objek pembelajarannya meliputi seluruh organisme uniseluler sampai organisme multiseluler, seluruh organisme prokaryotik sampai eukaryotik. Pembelajaran Biologi tidak harus selalu dengan membaca dan menghafal, tidak pula sekedar interaksi langsung antar siswa dengan objek belajar yang di pelajari yaitu ekosistem. Dijelaskan dalam standar kompetensi Biologi bahwa pembelajaran Biologi menekankan pada pemberian pengalaman secara langsung yang berkaitan dengan cara mencari tahu dan memahami. Sehubungan dengan hal tersebut siswa perlu dibantu untuk mengembangkan sejumlah keterampilan proses supaya mereka mampu menjelajah dan memahami dirinya sendiri. Oleh karena itu, model atau pendekatan yang diterapkan dalam menyajikan pembelajaran Biologi adalah memadukan antara pengalaman proses sains dan pemahaman produk sains. Belajar mengajar adalah suatu kegiatan antara guru dan murid yang bernilai edukatif. Interaksi yang bernilai edukatif dikarenakan kegiatan belajar mengajar yang dilakukan, diarahkan untuk mencapai tujuan tertentu yang telah dirumuskan sebelum pengajaran dilakukan. Guru dengan sadar merencanakan kegiatan pengajarannya secara sistematis dengan memanfaatkan segala sesuatunya guna kepentingan pengajaran. Harapan yang tidak pernah sirna dari guru adalah bagaimana bahan pelajaran yang disampaikan guru dapat diterima dan dipahami oleh peserta didik secara tuntas. Ini merupakan masalah yang cukup sulit yang dirasakan oleh guru. Kesulitan ini dikarenakan peserta didik bukan hanya sebagai individu dengan segala keunikannya, tetapi mereka juga sebagai mahluk sosial dengan latar belakang yang berbeda-beda. Selain itu ada aspek yang membedakan peserta didik yaitu aspek intelektual, psikologis, dan biologis. Ketiga aspek tersebut diakui sebagai akar permasalahan yang melahirkan bervariasinya sikap dan tingkah laku peserta didik di sekolah. Hal itu menjadi tugas yang cukup berat bagi guru dalam mengelola kelas dengan baik. Masalah pengelolaan kelas memang tidak pernah absen dari agenda kegiatan guru. Pengelolaan kelas yang baik akan melahirkan interaksi belajar mengajar yang baik pula. Pendidikan merupakan suatu proses pengubahan dan tata laku seseorang atau kelompok orang dalam usaha pendewasaan manusia melalui upaya pengajaran dan penelitian. Pendidikan dapat diartikan sebagai sebuah proses dengan model-model terentu sehingga orang memperoleh pengetahuan, pemahaman, dan cara betingkah laku yang sesuai dengan kebutuhan. Oleh karena itu model mempunyai peran yang cukup besar dalam kegiatan belajar mengajar. Kemampuan yang diharapkan dapat dimiliki peserta didik, akan ditentukan oleh kerelevansian penggunaan suatu model yang sesuai dengan tujuan pembelajaran. Itu berarti tujuan pembelajaran akan dapat dicapai dengan penggunaan model yang tepat, sesuai dengan standar keberhasilan yang terpatri dalam suatu tujuan. Rendahnya kualitas pendidikan yang dihasilkan tidak terlepas dari berbagai faktor diantaranya adalah pengemasan pembelajaran. Proses pembelajaran Biologi masih berorientasi pada penyelesaian masalah pada konteks materi, suasana kelas cenderung teacher centered sehingga siswa menjadi pasif saat pembelajaran dan ketercapaian kurikulum dengan didominasi oleh pembelajaran langsung. Model mengajar dapat diartikan sebagai cara menyajikan atau mengajarkan suatu materi pengajaran. Ini berarti model digunakan untuk merealisasikan rencana pembelajaran yang telah ditetapkan. Peranan model pembelajaran adalah alat untuk menciptakan proses mengajar dan belajar yang menyenangkan. Dengan model ini diharapkan tumbuh berbagai kegiatan belajar peserta didik sehubungan dengan kegiatan mengajar guru. Dengan demikian, model dalam rangkaian sistem pembelajaran memang memiliki peranan yang sangat penting. Model yang dapat dipergunakan dalam kegiatan belajar mengajar bermacam macam. Penggunaannya tergantung dari rumusan tujuan. Dalam mengajar, jarang ditemukan guru menggunakan satu model, tetapi kombinasi dari dua atau beberapa macam model. Penggunaan model gabungan dimaksudkan untuk menggairahkan belajar anak didik. 
Dengan bergairahnya belajar, peserta didik tidak sukar untuk mencapai tujuan pengajaran, sebab bukan guru yang memaksakan peserta didik untuk mencapai tujuan, melainkan peserta didiklah yang berperan aktif untuk mencapai tujuan pembelajaran. Penggunaan model yang bervariasi dapat membantu peserta didik dalam mencapai tujuan pembelajaran, karena peserta didik tidak merasa bosan atau jenuh dengan penggunaan satu model saja. Dalam mengajarkan konsep Biologi di SMA/MA, guru diharapkan mampu menggunakan model-model pembelajaran yang sesuai dengan materi yang akan diajarkan. Model Three Stage Fishbowl yang penuh dengan bentuk aktivitas peserta didik tentunya menekankan pentingnya peserta didik membangun sendiri pengetahuan mereka dalam proses belajar mengajar. Proses belajar mengajar lebih diwarnai student centered daripada teacher centered, arah pembelajaran tidak hanya berasal dari guru tetapi peserta didik juga dapat belajar dengan sesamanya. Selain itu, peserta didik tidak hanya mempelajari materi saja tetapi juga mempelajari keterampilan kooperatif. Keterampilan kooperatif ini berfungsi untuk melancarkan hubungan kerja dan tugas yang dapat dibangun dengan mengembangkan komunikasi antaranggota kelompok, sedangkan peranan tugas dilakukan dengan membagi tugas antar anggota kelompok selama kegiatan pembelajaran. Berdasarkan observasi yang telah dilakukan di sekolah SMA Swasta Persiapan Stabat, diketahui bahwa salah satu penyebab kurang berhasilnya siswa dalam mata pelajaran Biologi adalah karena siswa kurang mengerti konsep dan tidak merasakan kegunaan Biologi dalam kehidupannya. Selain itu pembelajaran lebih didominasi oleh guru sedangkan siswa hanya mendengarkan penjelasan guru dan mengerjakan tugas, sehingga banyak siswa yang kurang tertarik dengan pelajaran Biologi. Siswa cenderung bosan, takut dan kurang menyenangi pelajaran tersebut. Akibatnya hasil belajar masih rendah, sekitar 50\% siswa belum mencapai nilai Kriteria Ketuntasan Minimal (KKM) yaitu 75. Dengan demikian diperlukan usaha yang lebih optimal dari guru dan siswa.

\section{Perumusan Masalah}

Berdasarkan latar belakang masalah yang telah diuraikan di atas, maka dapat diidentifikasi masalah yang relevan dengan penelitian antara lain : Apakah ada pengaruh yang signifikan penggunaan model Three Stage Fishbowl terhadap hasil belajar siswa pada materi ekosistem di kelas X-3 SMA Swasta Persiapan Stabat Tahun Pembelajaran 2015/2016.

\section{Manfaat Penelitian}

Setiap orang melakukan kegiatan penelitian tentunya mempunyai tujuan tertentu sehingga kegiatan yang dilakukan mengandung manfaat baik untuk diri sendiri maupun untuk pihak

lain. Penelitian ini diharapkan mampu memberikan manfaat yaitu :

1. Bagi sekolah tempat penelitian, sebagai bahan pertimbangan dalam pengembangan dan penyempurnaan program pengajaran Biologi di sekolah.

2. Manfaat bagi guru, dengan hasil penelitian yang diperoleh dapat memberikan masukan bagi para guru tentang model pembelajaran Three Stage Fishbowl sebagai model pembelajaran yang lebih efektif.

3. Manfaat bagi sekolah, Hasil penelitian ini diharapkan dapat memberikan sumbangan yang baik pada sekolah tersebut dalam rangka perbaikan proses belajar mengajar di sekolah.

4. Manfaat bagi siswa, dengan penelitian ini diharapkan terjadinya perubahan pada diri siswa baik aspek kognitif, afektif, maupun psikomotorik sehingga bermanfaat bagi peningkatan hasil belajarnya. 
Anggun Ninda Syahputri, Edi Azwar : Pengaruh Model Three Stage Fishbowl Terhadap Hasil Belajar Siswa Pada Materi Ekosistem di Kelas X SMA Swasta Persiapan Stabat TP.2016/2017

\section{METODE PENELITIAN}

Metode yang digunakan dalam penelitian adalah metode eksperimen semu (quasi eksperiment) yaitu melaksanakan pembelajaran dengan model pembelajaran Three Stage

Fish Ball dengan desain sebagai berikut :

Desain Penelitian

\begin{tabular}{|c|c|c|c|}
\hline Kelas & Pre Test & Perlakuan & Post Test \\
\hline X IPA & TI & $\mathrm{X}$ & T2 \\
\hline
\end{tabular}

TI $=$ Pemberian Test Awal

$\mathrm{T} 2=$ Pemberian Test Akhir

$\mathrm{X}=$ Penggunaan Model Pembelajaran Three Stage Fish Ball

Langkah-langkah yang dilakukan dalam pengumpulan data adalah sebagai berikut:

1. Tahap Persiapan

a. Melakukan observasi

b. Mengajukan surat penelitian kepada fakultas

c. Mengajukan surat penelitian dari fakultas kepada pihak sekolah yang akan dijadikan sebagai tempat pelaksanaan penelitian

d. Merancang skenario pembelajaran untuk kelas yang menggunakan model pembelajaran Three Stage Fish Ball

e. Menyusun silabus

f. Menyusun renca pelaksanaan pembelajaran (RPP)

g. Membuat kisi-kisi soal dari materi pembelajaran yang akan diujikan

2. Tahap Pelaksanaan

a. Melaksanakan pre test untuk mengetahui kemampuan awal siswa

b. Menyampaikan materi kepada siswa dan melakukan proses pembelajaran dengan menggunakan Model pembelajaran Three Stage Fish Ball

c. Melaksanakan post test untuk mengetahui hasil belajar siswa setelah menerapkan model pembelajaran Three Stage Fish Ball

3. Tahap Penyelesaian

a. Melakukan pengolahan data.

b. Melakukan proses analisis data.

c. Menarik kesimpulan.

d. Menyusun laporan dengan melengkapi lampiran-lampiran yang berhubungan dengan penelitian

\section{Teknik Analisis Data}

Teknik analisis data dapat dicapai dengan langkah-langkah sebagai berikut:

1. Menentukan daftar distribusi frekuensi dengan rumus :Sudjana (2002:47)

a. Menentukan data tertinggidan data terendah

b. Menentukan Range (R) dari setiap kelas

c. Menentukan jumlah atau banyak kelas $B K=1+(3,3) \log n$

d. Menentukan panjang kelas interval : $\mathrm{P}=\mathrm{R} / \mathrm{BK}$

2. Menghitung Nilai Rata-Rata (Mean) dan Standar Deviasi dari setiap kelas.

a. Nilai Rata-Rata (Mean)

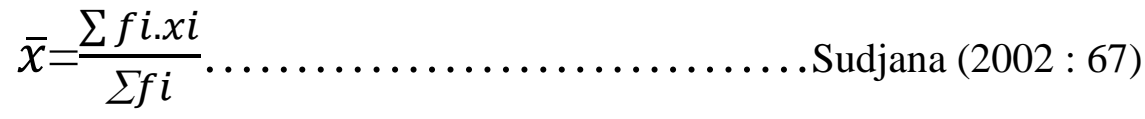


Keterangan :

$\bar{x}=$ Nilai/skor rata-rata kelas (Mean).

$\mathrm{f}_{\mathrm{i}} \quad$ frekuensi siswa yang mendapatkan nilai/skor sama

$\mathrm{x}_{\mathrm{i}}=$ nilai tes yang diperoleh pada salah satu kelas yang ada

b. Standar Deviasi atau disebut simpangan baku dapat dihitung dengan menggunakan rumus sebagai berikut:

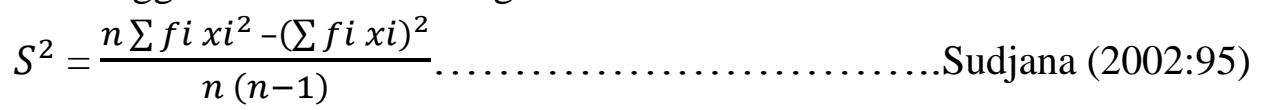

Keterangan :

$\mathrm{S} \quad=$ simpangan baku

$\mathrm{N} \quad=$ jumlah seluruh siswa

$\mathrm{f}_{\mathrm{i}} \quad=$ frekuensi yang sesuai dengan kelas $\mathrm{x}_{\mathrm{i}}$

$\mathrm{x}_{\mathrm{i}} \quad=$ nilai tengah kelas interval

\section{HASIL DAN PEMBAHASAN}

\section{Deskripsi Data Penelitian}

Data penelitian diperoleh dari hasil pre test dan post test pada materi Ekosistem. Data dihitung untuk mengetahui pengaruh model pembelajaran Three Stage Fishbowl terhadap hasil belajar siswa. Hasil belajar siswa dinyatakan tuntas jika nilai siswa sama atau lebih tinggi dari nilai Kriteria Kutuntasan Minimal ( KKM ) yaitu 75,00 yang ditentukan oleh sekolah SMA Swasta Persiapan Stabat. Dari hasil penelitian yang dilakukan dengan menggunakan model pembelajaran Three Stage Fishbowl pada materi Ekosistem di kelas X-3 SMA Swasta Persiapan Stabat Tahun Pembelajaran 2015/2016 yang berjumlah 30 siswa, dengan jumlah soal 20 butir soal untuk pre test dan 30 butir soal untuk post test. Berdasarkan hasil perhitungan yang telah dilakukan, diketahui jumlah kuadrat deviasi sebesar 2362,2 dengan menggunakan nilai tersebut maka dapat diketahui besar $t_{\text {hitung }}$ sebesar 9,93. Nilai $t_{\text {hitung }}$ yang diperoleh selanjutnya dibandingkan dengan nilai $t_{\text {tabel }}$ diketahui bahwa $t_{\text {hitung }}>t_{\text {tabel }}$ atau 9,93 > 1,70 maka Ha diterima dan Ho ditolak, sehingga dinyatakan bahwa ada pengaruh yang signifikan penggunaan model Three Stage Fishbowl terhadap hasil belajar siswa pada materi ekosistem

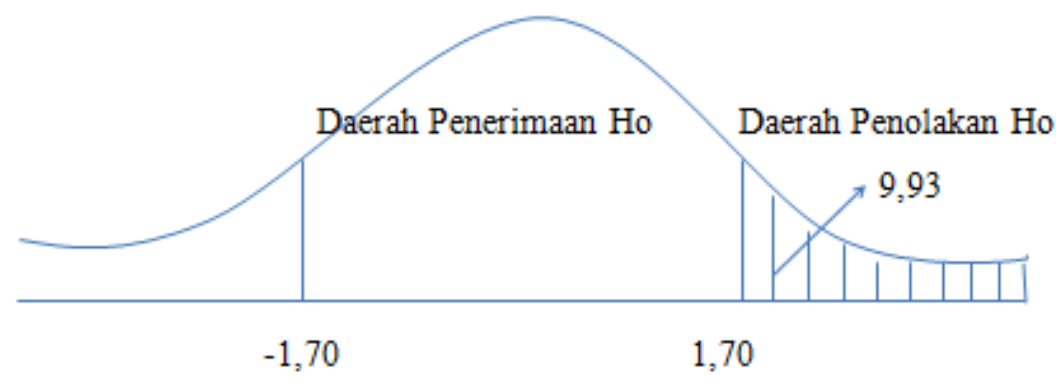

Model pembelajaran sangat dibutuhkan oleh para guru, sebab berhasil tidaknya siswa dalam belajar sangat tergantung pada tepatnya model pembelajaran yang digunakan sesuai dengan materi yang akan dipelajari sehingga pembelajaran yang dirancang dapat lebih bervariatif. Maka dalam penelitian ini pada materi Ekosistem khususnya pencemaran 
lingkungan model yang digunakan adalah model Three Stage Fishbowl .Penerapan Model pembelajaran Three Stage Fishbowl dimaksudkan untuk melatih siswa lebih aktif dan berfikir kritis dalam menciptakan solusi dari suatu masalah yang diberikan. (Elizabeth, 2012:128). Penerapan model Three Stage Fishbowl di dalam penelitian ini bertujuan untuk mengetahui data hasil belajar siswa sebelum dan sesudah diajar dengan menggunakan model pembelajaran Three Stage Fishbowl . Data yang diperoleh dalam penelitian ini terdiri atas dua jenis, pertama adalah data pre test yang diperoleh sebelum menerapkan model Three Stage Fishbowl, digunakan untuk melihat pengetahuan dasar atau kemampuan awal siswa mengenai materi ekosistem dan kedua adalah data post test atau data hasil belajar siswa setelah diberikan perlakuan atau penerapan model Three Stage Fishbowl sehingga nantinya akan terlihat pengaruh dari model Three Stage Fishbowl yang digunakan. Penggunaan model Three Stage Fishbowl ini menunjukkan peningkatan hasil belajar siswa. Data hasil belajar siswa sebelum penggunaan model pembelajaran Three Stage Fishbowl dengan melakukan tes kemampuan awal (pre test) diperoleh nilai rata- rata 59,56 dengan melihat hasil tersebut dapat diketahui bahwa nilai rata- rata pre test siswa masih dibawah Kriteria Ketuntasan Minimal (KKM) yang telah ditentukan oleh Sekolah SMA Swasta Persiapan Stabat yaitu 75. Hal ini disebabkan karena pada pelaksanaan pre test siswa diberikan soal tanpa sebelumnya dilakukan penerapan pembelajaran dengan menggunakan model Three Stage Fishbowl dan pembelajaran di kelas belum efektif, siswa belum mampu menyelesaikan soal dengan maksimal karena siswa kurang memahami serta kurang tertarik dalam kegiatan belajar yang dilakukan di kelas

\section{KESIMPULAN DAN SARAN}

\section{Kesimpulan}

Berdasarkan uraian penelitian di atas maka dapat diambil beberapa kesimpulan, yaitu:

1. Berdasarkan hasil analisis data yang diperoleh pada pre-test bahwa nilai rata-rata (X) hasil belajar siswa sebesar 59,56 standart deviasi sebesar 14,00 dengan jumlah KKM 75 siswa yang tuntas sebanyak 2 orang $(6,66 \%)$ dan yang tidak tuntas sebanyak 28 orang $(93,3 \%)$.

2. Berdasarkan hasil analisis data yang diperoleh pada post-test bahwa nilai rata-rata (X) hasil belajar siswa sebesar 74,56, standart deviasi sebesar 12,40 dengan jumlah KKM 75 siswa yang tuntas sebanyak 19 orang $(63,3 \%)$ dan yang tidak tuntas sebanyak 11 orang $(36,6 \%)$.

Berdasarkan hasil pre tes dan post test, hasil pada rata-rata, KKM mengalami peningkatan setelah diberikan perlakuan dengan menggunakan model Three Stage Fishbowl.

3. Berdasarkan hasil uji hipotesis maka diperoleh hasil $t_{\text {hitung }}>t_{\text {tabel }}$ yaitu $9,65>1,70$ pada taraf kepercayaan 0,05 maka terdapat pengaruh yang signifikan penggunaan model Three Stage Fishbowl terhadap hasil belajar siswa pada materi Ekosistem di kelas $\mathrm{X}^{3}$ SMA Swasta Persiapan Stabat Tahun Ajaran 2015/2016

\section{Saran}

Beberapa saran yang diusulkan berdasarkan penelitian, maka peneliti memberikan beberapa saran yaitu :

1. Bagi guru dan calon guru khususnya bidang studi Biologi menggunakan model Three Stage Fishbowl dapat dijadikan salah satu model pembelajaran di kelas untuk meningkatkan hasil belajar. 
Anggun Ninda Syahputri, Edi Azwar : Pengaruh Model Three Stage Fishbowl Terhadap Hasil Belajar Siswa Pada Materi Ekosistem di Kelas X SMA Swasta Persiapan Stabat TP.2016/2017

2. Disarankan untuk peneliti selanjutnya agar dalam proses kegiatan pembelajaran dapat mengantisipasi masalah dalam pembelajaran sehingga tidak menyita waktu belajar.

\section{DAFTAR PUSTAKA}

Arikunto, Suharsimi. 2006. Prosedur Suatu Pendekatan Praktik. Jakarta: Rienaka cipta

— 2012. dasar-dasar Evaluasi Pendididkan. Jakarta: Bumi Aksara

Asmani, Jamal M. 2009. Jurus-Jurus Belajar Efektif untuk SMP dan SMA. Jogjakarta: Diva Prees

Barkley, Elisabeth, dkk. 2012. Collaborative Learning Techniques: Tehnik-Tehnik Pembelajaran Kolaboratif. Bandung: Nusa Media

Dimyati, Mudjiono. 2009. Belajar dan Pembelajaran. Jakarta: Dirjen Dikti Depdikbud http://afhraboys.blogspot.co.id/2011/02/pencemaran-air_28.html http://gurunngeblog.com/2009/01/13polusi-atau-pencemaran-lingkungan/ http://lehawir.blogspot.com/2010/10/berbagi-ilmu-proposal-question-student.html http://dasar-teori.blogspot.com2011/pengertian-pendidikan-ipa-dan-perkembangannya http://lukmanp421.blogspot.com/2013/04/pencemaran-lingkungan-pabrik.html http://sayangialamsekitar.blogspot.com/2010/09/pencemaran-air.html http://www.anneahira.com/pencemaran-air-dan-udara.html http://www.artikellingkunganhidup.com/6-upayapencegahan-atas-pencemaranlingkungan.html

Mudjiono, D. 2006. Belajar dan Pembelajaran. Jakarta : Rieneka Cipta

Nurhayati, Nunung. 2013. Biologi untuk SMA Kelas X Peminatan. Bandung: Yrama Widya

Pratiwi, dkk. 2006. Biologi SMA Kelas X. Bandung: Erlangga

Purwanto. 2011. Evaluasi Hasil Belajar. Yogyakarta: Pustaka Belajar

Riana Yani, dkk. 2009. Biologi I Kelas X SMA dan MA. Jakarta: Pusat Perbukuan Departemen Pendidikan Nasional.

Silberman, Melvin L. 2013. Active Learning 101 Cara Belajar Siswa Aktiv. Jakarta: Nusa Media

Sri Widayati, dkk. 2009. Biologi SMA dan MA Kelas X. Jakarta: Pusat Perbukuan Departemen Pendidikan Nasional.

Subardi, Nuryani dan Shidiq Purnomo. 2009. Biologi untuk Kelas X SMA dan MA. Jakarta: CV Usaha Makmur 
Anggun Ninda Syahputri, Edi Azwar : Pengaruh Model Three Stage Fishbowl Terhadap Hasil Belajar Siswa Pada Materi Ekosistem di Kelas X SMA Swasta Persiapan Stabat TP.2016/2017

Suherman, Erman. 2001. Evaluasi Proses dan Hasil Belajar Matematika. Jakarta: Universitas Terbuka

Slameto. 2010. Belajar dan Faktor-Faktor yang mempengaruhinya. Jakarta: Rieneka Cipta Sudjana. 2002. Metode Statistik. Bandung: PT. Tarsito 